\title{
A Common Genetic Basis for Cross-sensitivity to Mesotrione and Nicosulfuron in Sweet Corn Hybrid Cultivars and Inbreds Grown throughout North America
}

\author{
Jerald K. Pataky ${ }^{1}$ \\ Department of Crop Sciences, University of Illinois, Urbana, IL 61801 \\ Martin M. Williams II \\ U.S. Department of Agriculture, Agricultural Research Service, Invasive Weed Management \\ Research, University of Illinois, Urbana, IL 61801 \\ Dean E. Riechers and Michael D. Meyer \\ Department of Crop Sciences, University of Illinois, Urbana, IL 61801
}

AdDITIONAL INDEX wORDs. cytochrome P450, herbicide selectivity, tolerance, Zea mays

\begin{abstract}
Mutation of a cytochrome P450 (CYP) gene on the short arm of chromosome five, referred to as nsf1 or ben 1, conditions sensitivity to certain P450-metabolized herbicides in corn (Zea mays L.). Previous research has shown that the sweet corn inbred $\mathrm{Cr} 1$ is sensitive to nicosulfuron, mesotrione, and at least seven other P450-metabolized herbicides with five different modes of action. Although the nsf1/ben1 CYP gene has not been sequenced from Cr1, a QTL that conditions cross-sensitivity to $\mathbf{P} 450$-metabolized herbicides was detected in a segregating population of Cr1 $\times$ Cr2 (herbicide tolerant) on the short arm chromosome five in tight linkage disequilibrium with the nsf1/ben1 CYP locus. Sweet corn hybrid cultivars and inbreds that had been identified in previous research as being susceptible to injury from P450-metabolized herbicides were tested in this study to determine if they were allelic with Cr1 for crosssensitivity to nicosulfuron and mesotrione. These cultivars and inbreds were developed by 12 independent commercial breeding programs. These cultivars include sugary, sugary enhancer, and shrunken-2 endosperm types that are grown for processing and fresh consumption in markets throughout North America and in other temperate climates throughout the world. Each hybrid cultivar, their $F_{2}$ progeny, and progeny from testcrosses of cultivars with $\mathrm{Cr} 1$ and $\mathrm{Cr} 2$ were evaluated for responses to mesotrione and nicosulfuron. Each inbred line, progeny from crosses of inbreds with $\mathrm{Cr} 1$ and $\mathrm{Cr} 2$, and $\mathrm{F}_{2}$ progeny from crosses of inbreds with $\mathrm{Cr} 1$ were also tested. Based on segregation of progeny from testcrosses with $\mathrm{Cr} 1$ and $\mathrm{Cr} 2$ and the $\mathrm{F}_{2}$ generation, 45 sweet corn hybrid cultivars and 29 sweet corn inbreds, including lines from each of the 12 breeding programs, appeared to be sensitive to nicosulfuron and mesotrione as the result of a gene that is the same as or very closely linked to the gene in Cr1. None of the cultivars or inbreds appeared to be sensitive to these herbicides as a result of other independent genes; however, additional genes that modify responses to these herbicides may be present in a few cases. The presence of a gene conditioning sensitivity to nicosulfuron and mesotrione, and probably to several other P450-metablolized herbicides, provides an explanation for varied levels of injury and inconsistent responses of sweet corn hybrid cultivars under differing environmental conditions. This information provides a basis from which an industry-wide concern with herbicide sensitivity in sweet corn can be addressed by various methods, including the elimination of an allele rendering germplasm sensitive.
\end{abstract}

Under certain environmental conditions in North America, some sweet corn hybrid cultivars and inbreds are injured by postemergence applications of cytochrome P450-metabolized

Received for publication 10 Nov. 2008. Accepted for publication 15 Jan. 2009. A portion of this research was supported by funding from the Midwest Food Processors Association.

Mention of a trademark, proprietary product, or vendor does not constitute a guarantee or warranty of the product by the U.S. Department of Agriculture and does not imply its approval to the exclusion of other products or vendors that also may be suitable.

We appreciate the cooperation of various seed and food processing companies that contributed seed of inbreds or hybrids for this study, including Abbott \& Cobb, Inc. (Feasterville, PA); Centest Inc. (Harvard, IL); Crookham Company (Caldwell, ID); Del Monte USA (Rochelle, IL); Green Giant Agriculture Research (LeSueur, MN); Harris Moran Seed Company (Modesto, CA); Illinois Foundation Seeds Inc. (Champaign, IL); Mesa Maize (Olathe, CO); Rogers Seeds/Syngenta (Boise, ID); Sakata Seed USA (Morgan Hill, CA); Seminis Vegetable Seeds (Oxnard, CA); and Snowy River Seeds (Orbost, Australia). We also thank Jim Moody and Bryan Warsaw for their technical assistance.

${ }^{1}$ Corresponding author. E-mail: j-pataky@illinois.edu. corn herbicides. Some of the sweet corn cultivars that are sensitive to specific herbicides have been identified in the past two decades in numerous field trials (Burton et al., 1994; Diebold et al., 2003, 2004; Grey et al., 2000; Monks et al., 1992; Morton and Harvey, 1992; O'Sullivan and Bouw, 1998; O'Sullivan and Sikkema, 2002; O'Sullivan et al., 1995, 2000, 2002; Robinson et al., 1993, 1994; Sikkema et al., 2008; Stall and Bewick, 1992; Williams and Pataky, 2008; Williams et al., 2005). Although useful, this information is limited because a relatively small percentage of nearly 600 sweet corn cultivars sold commercially in North America were tested in any one of these studies and the commercial availability of cultivars changes continually as new cultivars are introduced and older cultivars are discontinued. A better understanding of the genetic basis of herbicide sensitivity in sweet corn would help the sweet corn industry manage this problem more effectively and it may provide an explanation for varied responses of certain cultivars under differing conditions. 
In previous research, the sweet corn inbred $\mathrm{Cr} 1$ was found to be sensitive to multiple postemergence herbicides, including four acetolactate synthase (ALS)-inhibiting herbicides (foramsulfuron, nicosulfuron, primisulfuron, and rimsulfuron), two 4-hydroxyphenylpyruvate dioxygenase (HPPD)-inhibiting herbicides (mesotrione and tembotrione), a growth regulator herbicide combination (dicamba + diflufenzopyr), a protoporphyrinogen oxidase (PPO)-inhibiting herbicide (carfentrazone), and a photosystem II (PSII)-inhibiting herbicide (bentazon) (Nordby et al., 2008; Pataky et al., 2006; Williams and Pataky, 2008; Williams et al., 2005). Sensitivity to these herbicides appeared to be conditioned by a single gene or closely linked genes based on segregation of progeny in $\mathrm{F}_{2}, \mathrm{BC}_{1}$, and $\mathrm{BC}_{2}$ generations of a cross of $\mathrm{Cr} 1$ with $\mathrm{Cr} 2$ (a herbicide-tolerant inbred) and cosegregation of phenotypic responses among $\mathrm{BC}_{1} \mathrm{~S}_{1}$, $\mathrm{BC}_{2} \mathrm{~S}_{1}, \mathrm{~F}_{2: 3}, \mathrm{~F}_{3: 4}$, and $\mathrm{F}_{3: 5}$ families, (Nordby et al., 2008; Pataky et al., 2006; Williams and Pataky, 2008). Another independent gene from $\mathrm{Cr} 2$ also conditioned tolerance to bentazon.

These herbicides to which $\mathrm{Cr} 1$ is sensitive have different modes of action, but all are metabolized by cytochrome P450 monooxygenases. Barrett et al. (1994) previously proposed the existence of a "super P450" that metabolizes multiple herbicides. Although corn has many cytochrome P450 genes (CYP genes), the number of P450s involved in metabolic inactivation of herbicides, their expression levels, and their levels of herbicide metabolism are not clearly understood (Barrett, 1995, 2000; Frey et al., 1995, 1997; Persans et al., 2001).

A growing body of evidence suggests that sensitivity of corn to multiple $\mathrm{P} 450$-metabolized herbicides is regulated by a single CYP gene or a group of closely linked CYP genes on the short arm of chromosome 5. Kang (1993) associated nicosulfuron sensitivity in field corn inbred lines, including the inbred W703a, with a single, recessive gene designated as $n s f 1$. Others also reported simple inheritance of tolerant and sensitive responses to nicosulfuron and similar ALS-inhibiting herbicides (Green, 1998, Green and Ulrich, 1993; Harms et al., 1990; Widstrom and Dowler, 1995). Green (1998) cited an unpublished report that mapped sensitivity to rimsulfuron in the field corn inbred F2 to the short arm of chromosome 5. Fleming et al. (1988), Bradshaw et al. (1994), and Barrett et al. (1997) associated bentazon and nicosulfuron sensitivity in field corn inbreds B90 and GA209 with a single, recessive gene designated as ben1. An independent, dominant gene, designated as Ben2, conditioned tolerance to bentazon in the inbred B73 (Barrett et al., 1997; Bradshaw et al., 1994). Williams et al. (2006) used a mapped-based cloning approach to locate the Nsfl gene on the short arm of chromosome 5 and to sequence the dominant, functional allele from a nicosulfuron-tolerant inbred, B73. The Nsf1 gene was one of four closely linked genes with significant sequence similarity to CYP genes. The Nsfl gene also was very similar in sequence and function to a CYP gene in rice that conditions tolerant responses to multiple herbicides (Pan et al., 2006). Nicosulfuron-sensitive inbreds GA209 and W703a contained a 392-bp insertion in the Nsf1 gene sequence relative to B73. Thus, it appears that the $n s f 1$ and ben1 alleles identified from GA209 and W703a, respectively, are the same 392-bp insertion mutation of this CYP allele. The 392-bp insertion in this CYP gene sequence also occurs in several nicosulfuron-sensitive field corn inbreds (e.g., A180, B90, MS1334, NC22, and R4), whereas other nicosulfuronsensitive field and sweet corn inbreds (e.g., B94 and Ia5125) do not contain this insertion. The $n s f l /$ ben 1 CYP gene has not been sequenced from the herbicide-sensitive sweet corn inbred $\mathrm{Cr} 1$; however, a QTL that conditions sensitivity to multiple P450metabolized herbicides was detected in a segregating population of $\mathrm{Cr} 1 \times \mathrm{Cr} 2$ on the short arm chromosome 5 in tight linkage disequilibrium with the $n s f 1 / b e n 1$ CYP locus (Nordby et al., 2008).

The genetic condition at a single locus explained varied responses of 149 commercially adapted sweet corn hybrid cultivars to three P450-metabolized, postemergence herbicides (foramsulfuron, mesotrione, and nicosulfuron) in 12 field trials throughout the United States (Pataky et al., 2008). Seven cultivars classified as homozygous for alleles conditioning herbicide sensitivity were injured most severely and often were killed by the two ALS-inhibiting herbicides. Ninety-five cultivars classified as homozygous for an allele conditioning herbicide tolerance were uninjured or injured least. Forty-seven cultivars classified as heterozygous with one allele each conditioning herbicide tolerance and sensitivity displayed intermediate responses that were more similar to homozygous tolerant cultivars than homozygous sensitive cultivars. Injury to heterozygous and homozygous tolerant cultivars was minimal and often not significantly different in trials in dry, western climates (e.g., Caldwell, ID; Nampa, ID; and Olathe, CO), whereas injury to heterozygous cultivars was significantly greater than injury to homozygous tolerant cultivars in trials in eastern climates (e.g., Georgetown, DE and LeRoy, NY). Nevertheless, it was not evident that the seven homozygous sensitive cultivars and the 49 heterozygous cultivars carried the same allele conditioning sensitivity. The objective of this study was to determine if sensitivity to nicosulfuron and mesotrione among commercially adapted, sweet corn cultivars and inbreds is allelic with or closely linked to the recessive gene conditioning sensitivity in the sweet corn inbred $\mathrm{Cr} 1$.

\section{Materials and Methods}

Plant materials and Crosses. Fifty-four sweet corn cultivars (i.e., hybrids) and 40 sweet corn inbreds were evaluated in this study. All of the sweet corn cultivars and most of the inbreds were obtained from 12 independent commercial breeding programs. Most of the cultivars were selected based on their potential for herbicide injury as indicated from results of previous public or proprietary trials, although some herbicide-tolerant controls also were included. Fifteen of the 54 cultivars in this study were among the 47 cultivars heterozygous for alleles conditioning herbicide tolerance and sensitivity in a previous study (Pataky et al., 2008). The group of cultivars in this study included those grown for processing and fresh market as well as white, yellow, or bicolored sweet corn with sugary, sugary enhancer, or shrunken-2 endosperm types. Thirty-seven proprietary sweet corn inbreds from nine commercial breeding programs were selected by their breeders as representative of herbicide-sensitive and -tolerant inbreds. The three major endosperm types and processing and fresh market types of sweet corn also were represented by this group of inbreds. Three nicosulfuron-sensitive, public sweet corn inbreds (Ia5125, Ia5125sh2, and IL14h) also were evaluated.

Hybrid cultivars and inbreds were planted in pollination nurseries in 2005 with pollinator rows of $\mathrm{Cr} 1, \mathrm{Cr} 2$, and three nicosulfuron-sensitive, field corn inbreds (B90, B94, and GA209). Cr1 is a nicosulfuron- and mesotrione-sensitive sweet corn inbred. Cr-2 is a nicosulfuron- and mesotrione-tolerant 
sweet corn inbred. B90 and GA209 have the same 392-bp insertion in the Nsf1/Ben1 CYP gene sequence as W703A, but B94 does not have this insertion nor does the sweet corn inbred Ia5125 (Williams et al., 2006). Each sweet corn cultivar was self pollinated to produce seed of $\mathrm{F}_{2}$ progeny. Each cultivar also was crossed with $\mathrm{Cr} 1, \mathrm{Cr} 2$, and one or more of the three field corn inbreds to produce testcross progeny. Each sweet corn inbred also was crossed with $\mathrm{Cr} 1, \mathrm{Cr} 2$, and one or more of the three herbicide-sensitive field corn inbreds. $\mathrm{F}_{1}$ progeny from crosses of sweet corn inbreds with $\mathrm{Cr} 1$ were self pollinated in a winter nursery in Chile to produce seed of $F_{2}$ progeny. The three field corn inbreds also were crossed with $\mathrm{Cr} 1$ and $\mathrm{Cr} 2$.

Field EVAluAtions OF RESPONSES TO NiCOSULFURON AND MESOTRIONE. Sweet corn cultivars, sweet corn inbreds, field corn inbreds, and progeny from crosses were evaluated for responses to nicosulfuron and mesotrione in field trials in 2006 and 2007. Four separate trials were planted each year for each combination of two groups of plant materials (i.e., cultivars and inbreds) and two herbicides. Each trial included two replicates of plant materials arranged in randomized blocks of a split-plot experimental design. Main plots were planted with all of the crosses derived from a cultivar or an inbred. For sweet corn cultivars, the number of rows of each subplot varied according to the generation being evaluated and availability of seed, and included one row of the cultivar, three rows of the $\mathrm{F}_{2}$ generation, two rows of the Cr1-testcross, and one row each of the Cr2-testcross and testcrosses with field corn inbreds. For sweet corn inbreds, subplots were one row each of the inbred, the $\mathrm{F}_{1}$ hybrids from crosses with $\mathrm{Cr} 1, \mathrm{Cr} 2$, and field corn inbreds, and the $\mathrm{F}_{2}$ generation from the cross with $\mathrm{Cr} 1$. In all trials, each row was $\approx 3.1 \mathrm{~m}$ in length with 12 to 22 plants per row, depending on availability and germination of seed. Trials were planted 8 May 2006 and 3 May 2007. One row each of Cr1, Cr2, Cr1 × $\mathrm{Cr} 2$, and a sensitive sweet corn cultivar (Merit) were included in each replicate of each trial. One row each of B90, B94, and the $\mathrm{F}_{1}$ hybrids: $\mathrm{Cr} 1 \times \mathrm{B} 90, \mathrm{Cr} 1 \times \mathrm{B} 94, \mathrm{Cr} 2 \times \mathrm{B} 90, \mathrm{Cr} 2 \times \mathrm{B} 94$, B90 × GA209, and B94 × GA209 also were included in each replicate of the cultivar trials.

Commercial formulations of herbicides were applied when plants had leaves with four to six visible collars. In both years, nicosulfuron was applied at $70 \mathrm{~g} \cdot \mathrm{ha}^{-1}$ with $1 \%(\mathrm{v} / \mathrm{v})$ crop oil concentrate (COC) and $3.6 \%$ (v/v) spray solution of $28 \%$ urea ammonium nitrate (UAN). This rate, which is twice the recommended usage rate in corn, was used to ensure distinct differences between sensitive and tolerant responses. In 2006, mesotrione was applied at $158 \mathrm{~g} \cdot \mathrm{ha}^{-1}$ with $1 \%(\mathrm{v} / \mathrm{v}) \mathrm{COC}$ and $2.5 \%(\mathrm{v} / \mathrm{v})$ spray solution of $28 \%$ UAN. This rate, which is 1.5 times the recommended usage rate in corn, also was used to ensure distinct differences between sensitive and tolerant responses; however, intermediate responses to mesotrione occurred in 2006 that often were difficult to differentiate from sensitive responses. Therefore, in 2007, mesotrione was applied at the recommended usage rate of $105 \mathrm{~g} \cdot \mathrm{ha}^{-1}$ with $1 \%(\mathrm{v} / \mathrm{v})$ COC and $2.5 \%(\mathrm{v} / \mathrm{v})$ spray solution of $28 \%$ UAN.

Plants were rated visually for injury 13 to $15 \mathrm{~d}$ after application of nicosulfuron and 6 to $8 \mathrm{~d}$ after application of mesotrione. Phenotypic responses were easily differentiated 2 weeks after application of nicosulfuron, as plants were healthy and green (i.e., tolerant phenotype) or nearly dead (i.e., sensitive phenotype). An occasional plant that was severely wilted or dead because of root-feeding insects, root rots, or other causes may have been mistakenly classified as sensitive to nicosulfuron although it was actually tolerant. Stunting or other quantitative measures of injury from nicosulfuron were not recorded. Thus, plants that were stunted but not killed by nicosulfuron were classified as tolerant. Phenotypic responses also were distinct $7 \mathrm{~d}$ after application of mesotrione, although many plants displayed an intermediate phenotype in 2006 when a $1.5 \times$ rate of herbicide was applied. Tolerant plants were healthy and green, whereas leaves growing from leaf whorls of sensitive plants were chlorotic and bleached. In 2006, some plants had chlorotic tissues occurring in a $1-$ to $5-\mathrm{cm}$ band on leaves about 3 to $7 \mathrm{~cm}$ above the whorl. The chlorotic area appeared to be the leaf tissue that formed the whorl on the day that mesotrione was applied. Plants with these intermediate phenotypes were grouped with tolerant responses, although in some instances the difference between intermediate and sensitive phenotypes was subjective; thus, some plants were undoubtedly misclassified. Therefore, segregation of responses to mesotrione was analyzed from data collected in 2007 when phenotypes were more definitive.

The chi-square goodness of fit test was used to determine if the number of tolerant and sensitive plants in segregating generations was different from the ratio expected if the response to these herbicides was conditioned by a single gene that was allelic with or closely linked to the gene in $\mathrm{Cr} 1$. Nicosulfuron data were combined from a total of four replicates from trials in 2006 and 2007. Mesotrione data were from two replicates from trials in 2007.

\section{Results}

Across all trials, 99\% of inbred and hybrid control plants displayed expected responses to nicosulfuron and mesotrione. None of 308 plants of the tolerant inbred $\mathrm{Cr} 2$ were injured by nicosulfuron or mesotrione, whereas 280 of 284 plants of the sensitive inbred Cr1 were injured. Similarly, only 6 of 342 plants of the $\mathrm{F}_{1}$ hybrid $\mathrm{Cr} 1 \times \mathrm{Cr} 2$ were injured while 382 of 386 plants of the sensitive hybrid 'Merit' were injured.

SWEET CORN HYBRID CULTIVARS. Nine cultivars were classified as homozygous tolerant and eight cultivars were classified as homozygous sensitive to nicosulfuron and mesotrione (Tables 1 and 2). Thirty-seven cultivars were classified as heterozygous for alleles conditioning response to mesotrione and nicosulfuron (Tables 2 and 3 ).

None of 1518 plants of the nine homozygous tolerant cultivars were sensitive to nicosulfuron or mesotrione, and only 14 of 7597 progeny $(0.2 \%)$ of these cultivars in the $F_{2}$ generation and in testcross generations with $\mathrm{Cr} 1$ and $\mathrm{Cr} 2$ were sensitive (Table 2). Based on $99.9 \%$ tolerant $\mathrm{F}_{2}$ progeny, these cultivars were considered to be homozygous for an allele conditioning tolerance to nicosulfuron and mesotrione.

Among eight cultivars classified as homozygous sensitive, $98 \%$ of 1050 plants were sensitive to nicosulfuron or mesotrione, and $99 \%$ of 4631 progeny in the $\mathrm{F}_{2}$ and the Cr1-testcross generations were sensitive (Table 2). Only 4 of 247 progeny from testcrosses of these cultivars with $\mathrm{Cr} 2$ were sensitive. Based on $98.3 \%$ sensitive $\mathrm{F}_{2}$ progeny and $99.6 \%$ sensitive progeny from testcrosses with $\mathrm{Cr} 1$, these eight cultivars were considered to be homozygous for an allele that is the same as or very closely linked to an allele in $\mathrm{Cr} 1$ that conditions sensitivity to nicosulfuron and mesotrione.

Among the 37 seven hybrid cultivars classified as heterozygous, 25 of $4717 \mathrm{~F}_{1}$ plants were sensitive to nicosulfuron or 
Table 1. Sweet corn hybrid cultivars classified as homozygous for alleles conditioning a tolerant or sensitive response to nicosulfuron and mesotrione.

\begin{tabular}{llll}
\hline $\begin{array}{l}\text { Cultivars with a } \\
\text { tolerant response }\end{array}$ & $\begin{array}{c}\text { Seed } \\
\text { source }^{z}\end{array}$ & $\begin{array}{c}\text { Cultivars with a } \\
\text { sensitive response }\end{array}$ & Seed source $^{\text {z }}$ \\
\hline Conquest & Cr & 177A & IFSI \\
Empire & Rog & CrshYP3-112 & Cr \\
GSS 6314 & Rog & DMC 20-38 & DM \\
HMX 2374 BS & HM & EX 087 0 5770 & Sem \\
HY1558 & SnRv & Gallant & Cr \\
Intrique & Cr & HY 1734 & SnRv \\
Rustler & HM & Kahuna & SnRv \\
Snow White & HM & Shogun & Cr \\
Twin Star & HM & &
\end{tabular}

${ }^{{ }^{z} \mathrm{Cr}}=$ Crookham (Caldwell, ID); DM = Del Monte USA (Rochelle, IL); $\mathrm{HM}=$ Harris Moran (Modesto, CA); IFSI = Illinois Foundation Seeds (Champaign, IL); Rog = Rogers Seeds/Syngenta (Boise, ID); Sem = Seminis Vegetable Seeds (Oxnard, CA); SnRv = Snowy River (Orbost, Australia).

mesotrione, and 4 of 2843 progeny from testcrosses with $\mathrm{Cr} 2$ were sensitive (Table 2). For the entire group of 37 heterozygous cultivars, $21.3 \%$ of $9120 \mathrm{~F}_{2}$ progeny were sensitive and $48.4 \%$ of $8080 \mathrm{Cr} 1$-testcross progeny were sensitive (Table 2 ).

Individually, for each of the 37 cultivars classified as heterozygous, $\mathrm{F}_{2}$ progeny and Cr1-testcross progeny segregated for tolerant and sensitive plants in ratios that usually were not significantly different from $3: 1$ and $1: 1$, respectively, which would be expected if a single allele in the cultivar conditioned sensitivity and that allele was the same as or closely linked to the QTL conditioning sensitivity in Cr1 (Table 3). Segregation in the Cr1-testcross generation treated with nicosulfuron or mesotrione was not significantly different $(P>0.05)$ from a 1:1 ratio of tolerant:sensitive progeny for 36 of the 37 heterozygous cultivars (Table 3). Only GH 2298 segregated significantly different from 1:1 with a greater than expected number of progeny tolerant to nicosulfuron and mesotrione. Segregation in the $\mathrm{F}_{2}$ generation treated with nicosulfuron or mesotrione was not significantly different $(P>0.01)$ from a 3:1 ratio of tolerant:sensitive progeny for 24 of the 37 cultivars classified as heterozygous (Table 3 ). In all 10 instances where segregation of
$\mathrm{F}_{2}$ progeny did not fit a 3:1 ratio following application of nicosulfuron, the number of sensitive $F_{2}$ progeny was less than expected. This may have occurred because some sensitive progeny were stunted rather than killed 2 weeks after application of nicosulfuron and thus were misclassified as tolerant. In the four instances where segregation of $\mathrm{F}_{2}$ progeny did not fit a $3: 1$ ratio following application of mesotrione, the number of sensitive $F_{2}$ progeny was greater than expected. This may have occurred because some heterozygous $\mathrm{F}_{2}$ progeny with an intermediate response were was classified as sensitive rather than tolerant.

SWEET CORN INBREDS. Eleven sweet corn inbreds were classified as tolerant and 29 sweet corn inbreds were classified as sensitive to nicosulfuron and mesotrione (Table 4). Two of the 29 sensitive inbreds differed in response to nicosulfuron and mesotrione. One of the 29 sensitive inbreds appeared to be segregating for response to nicosulfuron and mesotrione.

Among the 11 inbreds classified as tolerant, only 2 of 619 inbred plants were sensitive to nicosulfuron or mesotrione, and only 4 of the 3144 progeny from testcrosses with $\mathrm{Cr} 1$, field corn inbreds, or $\mathrm{Cr} 2$ were sensitive to nicosulfuron or mesotrione (Table 4). Segregation of $F_{2}$ progeny from crosses of the 11 tolerant inbreds with $\mathrm{Cr} 1$ was not significantly different $(P>$ $0.05)$ from a 3:1 ratio (tolerant:sensitive) for the entire group (i.e., 965:350) or for any of the 22 individual analyses of $F_{2}$ progeny treated with nicosulfuron or mesotrione (data not shown).

Among 26 inbreds with uniformly sensitive responses to nicosulfuron and mesotrione, $98.9 \%$ of 1710 inbred plants, $99.9 \%$ of 2647 progeny from crosses of the inbreds with $\mathrm{Cr} 1$, $99.8 \%$ of $2852 \mathrm{~F}_{2}$ progeny from those crosses, and $99.6 \%$ of 2135 progeny from crosses of the inbreds with field corn inbreds B90, B94, and GA209 were sensitive to nicosulfuron and mesotrione (Table 4). Twelve of 2698 progeny from crosses of these 26 inbreds and $\mathrm{Cr} 2$ were classified as sensitive. Based on homogeneous sensitive responses of $\mathrm{F}_{1}$ progeny from crosses with $\mathrm{Cr} 1, \mathrm{~B} 90, \mathrm{~B} 94$, and GA209, and $\mathrm{F}_{2}$ progeny from crosses with $\mathrm{Cr} 1$, these 26 inbreds were considered to be homozygous for an allele that conditions sensitivity to nicosulfuron and mesotrione. This allele occurs at the same chromosomal location as the allele that conditions herbicide sensitivity in $\mathrm{Cr} 1$ and three field corn inbreds.

Table 2. Number of tolerant and sensitive progeny in $\mathrm{F}_{1}, \mathrm{~F}_{2}$, and testcross ${ }^{z}$ generations for sweet corn hybrid cultivars classified as homozygous tolerant, homozygous sensitive, or heterozygous for alleles conditioning response to nicosulfuron and mesotrione.

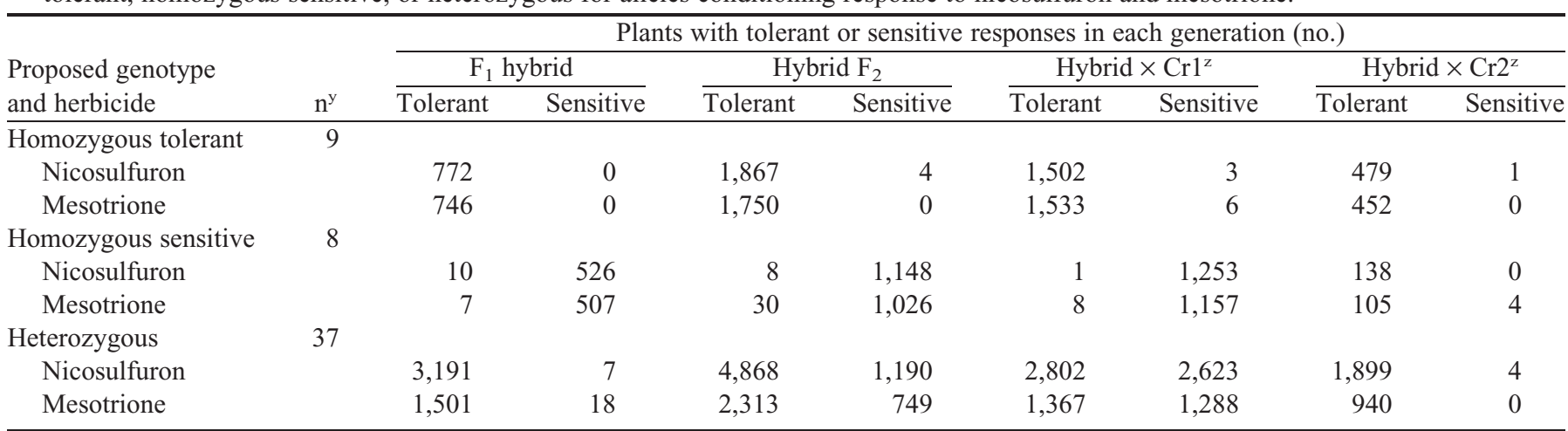

${ }^{\mathrm{z} T e s t c r o s s e s}$ of F1 hybrid cultivars with Cr1 (a nicosulfuron- and mesotrione-sensitive inbred) and with Cr2 (a nicosulfuron- and mesotrionetolerant inbred).

$\mathrm{y}_{\mathrm{n}}=$ number of hybrid cultivars. 
Table 3. Number of tolerant and sensitive testcross ${ }^{z}$ and $F_{2}$ progeny for sweet corn hybrid cultivars classified as heterozygous for alleles conditioning response to nicosulfuron and mesotrione.

\begin{tabular}{|c|c|c|c|c|c|c|c|c|c|c|c|c|c|}
\hline \multirow[b]{4}{*}{ Cultivar } & \multirow{4}{*}{$\begin{array}{c}\text { Seed } \\
\text { source }^{\mathrm{y}}\end{array}$} & \multicolumn{12}{|c|}{ Plants with tolerant or sensitive responses (no.) and chi-square probabilities } \\
\hline & & \multicolumn{6}{|c|}{ Cultivar $\times$ Cr1 testcross ${ }^{z}$} & \multicolumn{6}{|c|}{$\mathrm{F}_{2}$ generation } \\
\hline & & \multicolumn{3}{|c|}{ Nicosulfuron } & \multicolumn{3}{|c|}{ Mesotrione } & \multicolumn{3}{|c|}{ Nicosulfuron } & \multicolumn{3}{|c|}{ Mesotrione } \\
\hline & & $\mathrm{T}^{\mathrm{x}}$ & $\mathrm{S}^{\mathrm{x}}$ & $P^{\mathrm{x}}$ & $\mathrm{T}$ & $\mathrm{S}$ & $P$ & $\mathrm{~T}$ & $\mathrm{~S}$ & $P$ & $\mathrm{~T}$ & $\mathrm{~S}$ & $P$ \\
\hline \multicolumn{14}{|c|}{ Segregation in all generations fit expected ratios } \\
\hline $178 \mathrm{~A}$ & IFSI & 78 & 79 & 0.94 & 25 & 29 & 0.59 & 93 & 22 & 0.15 & 42 & 22 & 0.08 \\
\hline Argent & $\mathrm{Cr}$ & 79 & 66 & 0.28 & 24 & 27 & 0.67 & 104 & 39 & 0.53 & 56 & 24 & 0.30 \\
\hline Brocade & MM & 71 & 75 & 0.74 & 32 & 39 & 0.41 & 86 & 20 & 0.14 & 35 & 9 & 0.4 \\
\hline Celestial & $\mathrm{Cr}$ & 58 & 58 & 1.00 & 31 & 26 & 0.51 & 156 & 43 & 0.27 & 46 & 17 & 0.72 \\
\hline Coho & HM & 97 & 87 & 0.46 & 35 & 38 & 0.73 & 155 & 74 & 0.01 & 73 & 37 & 0.04 \\
\hline CshBF3-122 & $\mathrm{Cr}$ & 76 & 78 & 0.87 & 38 & 37 & 0.91 & 85 & 25 & 0.58 & 64 & 21 & 0.95 \\
\hline CsuWP1-7 & $\mathrm{Cr}$ & 63 & 58 & 0.65 & 39 & 30 & 0.28 & 154 & 49 & 0.78 & 62 & 30 & 0.09 \\
\hline Double Gem & MM & 72 & 75 & 0.80 & 39 & 44 & 0.58 & 78 & 38 & 0.05 & 60 & 13 & 0.16 \\
\hline Eliminator & $\mathrm{Cr}$ & 84 & 89 & 0.70 & 33 & 33 & 1.00 & 173 & 36 & 0.01 & 67 & 24 & 0.76 \\
\hline GG Code 17 & GG & 72 & 68 & 0.74 & 36 & 39 & 0.73 & 164 & 44 & 0.20 & 71 & 17 & 0.22 \\
\hline GH 2669 & Rog & 91 & 88 & 0.82 & 49 & 48 & 0.92 & 205 & 63 & 0.57 & 115 & 27 & 0.10 \\
\hline Ivanhoe & MM & 6 & 5 & 0.76 & 6 & 5 & 0.76 & 121 & 31 & 0.19 & 67 & 13 & 0.07 \\
\hline Jubilee & Rog & 90 & 73 & 0.18 & 46 & 38 & 0.38 & 219 & 68 & 0.61 & 101 & 26 & 0.24 \\
\hline K3-312 & Sak & 64 & 56 & 0.47 & 37 & 30 & 0.39 & 108 & 25 & 0.10 & 46 & 18 & 0.56 \\
\hline Merkur & Sem & 77 & 85 & 0.53 & 41 & 37 & 0.65 & 161 & 38 & 0.05 & 69 & 23 & 1.00 \\
\hline Mirai 002 & Cent & 89 & 87 & 0.88 & 35 & 34 & 0.90 & 41 & 6 & 0.05 & 17 & 4 & 0.53 \\
\hline Mystique & $\mathrm{Cr}$ & 37 & 34 & 0.72 & 15 & 22 & 0.25 & 76 & 21 & 0.45 & 43 & 10 & 0.30 \\
\hline SCH 70064 RR & IFSI & 93 & 78 & 0.25 & 40 & 43 & 0.74 & 175 & 57 & 0.88 & 90 & 29 & 0.87 \\
\hline Silver Queen & $\operatorname{Rog}$ & 99 & 82 & 0.21 & 56 & 38 & 0.06 & 187 & 66 & 0.69 & 95 & 30 & 0.80 \\
\hline SS Jubilee & Rog & 66 & 70 & 0.73 & 52 & 45 & 0.48 & 73 & 21 & 0.55 & 45 & 16 & 0.82 \\
\hline SS Jubilee Plus & Rog & 55 & 50 & 0.63 & 30 & 37 & 0.39 & 109 & 36 & 0.96 & 46 & 19 & 0.43 \\
\hline UY 0657 & $\mathrm{SnRv}$ & 85 & 70 & 0.23 & 39 & 48 & 0.33 & 151 & 43 & 0.36 & 88 & 22 & 0.23 \\
\hline ХTH 2477 & IFSI & 64 & 69 & 0.66 & 45 & 37 & 0.38 & 62 & 12 & 0.08 & 55 & 11 & 0.12 \\
\hline \multicolumn{14}{|c|}{ Segregation in the $\mathrm{F}_{2}$ generation treated with nicosulfuron did not fit the expected ratio } \\
\hline $277 \mathrm{~A}$ & IFSI & 57 & 64 & 0.52 & 32 & 29 & 0.70 & 79 & 8 & 0.001 & 65 & 13 & 0.09 \\
\hline Bold & $\operatorname{Rog}$ & 81 & 87 & 0.64 & 41 & 32 & 0.29 & 175 & 30 & 0.001 & 79 & 22 & 0.46 \\
\hline El Toro & Sem & 76 & 69 & 0.56 & 32 & 31 & 0.90 & 179 & 34 & 0.002 & 71 & 12 & 0.03 \\
\hline GH 0991 & Rog & 97 & 88 & 0.51 & 48 & 41 & 0.46 & 205 & 42 & 0.004 & 88 & 28 & 0.83 \\
\hline Hollywood & Sem & 72 & 72 & 1.00 & 50 & 36 & 0.13 & 164 & 14 & $>0.001$ & 81 & 23 & 0.50 \\
\hline How Sweet It Is & $\mathrm{Cr}$ & 87 & 75 & 0.35 & 37 & 33 & 0.63 & 91 & 11 & 0.001 & 53 & 16 & 0.73 \\
\hline Mirai 003 & Cent & 66 & 86 & 0.10 & 21 & 25 & 0.56 & 95 & 7 & $>0.001$ & 45 & 9 & 0.16 \\
\hline Polaris & $\mathrm{HM}$ & 84 & 67 & 0.17 & 42 & 35 & 0.43 & 86 & 4 & $>0.001$ & 36 & 9 & 0.44 \\
\hline XTH 1173 & IFSI & 69 & 61 & 0.48 & 37 & 43 & 0.50 & 159 & 17 & $>0.001$ & 57 & 30 & 0.04 \\
\hline \multicolumn{14}{|c|}{ Segregation in the $\mathrm{F}_{2}$ generation treated with mesotrione did not fit the expected ratio } \\
\hline $170 \mathrm{~A}$ & IFSI & 75 & 77 & 0.87 & 33 & 39 & 0.48 & 66 & 15 & 0.18 & 29 & 22 & 0.003 \\
\hline Millenium & Sak & 92 & 81 & 0.40 & 37 & 40 & 0.73 & 118 & 45 & 0.44 & 40 & 26 & 0.007 \\
\hline ХTH 1178 & IFSI & 78 & 80 & 0.87 & 45 & 36 & 0.32 & 157 & 19 & 0.01 & 53 & 33 & 0.004 \\
\hline
\end{tabular}

XTH 1178

Segregation in the $\mathrm{F}_{2}$ generation treated with nicosulfuron and mesotrione did not fit the expected ratio

$\begin{array}{llllllllllllll}\text { Code } 61 & \text { GG } & 83 & 80 & 0.81 & 30 & 38 & 0.33 & 149 & 22 & >0.001 & 86 & 12 & 0.004\end{array}$ Segregation in the Cr1-testcross generation treated with nicosulfuron and mesotrione did not fit the expected ratio

$\begin{array}{llrrrrrrrrrrrr}\text { GH 2298 } & \text { Rog } & 119 & 56 & >0.001 & 65 & 31 & 0.001 & 209 & 46 & 0.01 & 87 & 22 & 0.25 \\ \text { Total } & & 2,802 & 2,623 & & 1,373 & 1,293 & & 4,868 & 1,191 & & 2,323 & 739 & \end{array}$

${ }^{\mathrm{z}}$ Testcross of $\mathrm{F}_{1}$ hybrid cultivars with $\mathrm{Cr} 1$ (a nicosulfuron- and mesotrione-sensitive inbred).

${ }^{y}$ Cent $=$ Centest $($ Harvard, IL); Cr = Crookham (Caldwell, ID); GG = Green Giant (LeSueur, MN); HM = Harris Moran $($ Modesto, CA); IFSI = Illinois Foundation Seeds (Champaign, IL); MM = Mesa Maize (Olathe, CO); Rog = Rogers/Syngenta (Boise, ID); Sak = Sakata Seed USA (Morgan Hill, CA): Sem = Seminis Vegetable Seeds (Oxnard, CA); SnRv = Snowy River (Orbost, Australia).

${ }^{x} \mathrm{~T}=$ tolerant, $\mathrm{S}=$ sensitive, and $P=$ probability associated with a chi-square goodness of fit test for $1: 1$ segregation of testcross progeny and $3: 1$ segregation of $\mathrm{F}_{2}$ progeny for tolerant and sensitive responses.

Two inbreds classified as sensitive had different responses to nicosulfuron and mesotrione (Table 4). All 94 plants of these two inbreds were sensitive to mesotrione, but only 10 of 94 plants were sensitive to nicosulfuron. Nevertheless, all $275 \mathrm{~F}_{1}$ progeny from crosses with $\mathrm{Cr} 1$ and 336 of $344 \mathrm{~F}_{2}$ progeny from those crosses were sensitive to nicosulfuron or mesotrione. All 53 progeny from crosses with sensitive field corn inbreds were sensitive to mesotrione, but only 42 of 61 progeny from crosses with sensitive field corn inbreds were sensitive to nicosulfuron. Two weeks after application of nicosulfuron, plants of these 
Table 4. Number of plants tolerant and sensitive to nicosulfuron and mesotrione for 40 sweet corn inbreds and their $F_{1}$ progeny from crosses with $\mathrm{Cr} 1-, \mathrm{Cr} 2-$, and herbicide-sensitive field corn inbreds and the $\mathrm{F}_{2}$ progeny from crosses with $\mathrm{Cr} 1$.

\begin{tabular}{|c|c|c|c|c|c|c|c|c|c|c|c|}
\hline \multirow{3}{*}{$\begin{array}{l}\text { Proposed response } \\
\text { and herbicide }\end{array}$} & \multirow[b]{3}{*}{$\mathrm{n}^{\mathrm{v}}$} & \multicolumn{10}{|c|}{ Plants with tolerant or sensitive responses to nicosulfuron or mesotrione in each generation (no.) } \\
\hline & & \multicolumn{2}{|c|}{ Inbred $^{\mathrm{z}}$} & \multicolumn{2}{|c|}{ Inbred $\times \mathrm{Cr}^{\mathrm{y}}$} & \multicolumn{2}{|c|}{$($ Inbred $\times \mathrm{Cr} 1) \mathrm{F}_{2}$} & \multicolumn{2}{|c|}{ Inbred $\times$ field corn $^{\mathrm{w}}$} & \multicolumn{2}{|c|}{ Inbred $\times \mathrm{Cr}^{\mathrm{x}}$} \\
\hline & & Tolerant & Sensitive & Tolerant & Sensitive & Tolerant & Sensitive & Tolerant & Sensitive & Tolerant & Sensitive \\
\hline Tolerant & 11 & & & & & & & & & & \\
\hline Nicosulfuron & & 366 & 2 & 792 & 0 & 634 & 232 & 234 & 0 & 679 & 0 \\
\hline Mesotrione & & 251 & 0 & 452 & 3 & 331 & 118 & 259 & 1 & 724 & 0 \\
\hline Sensitive & 26 & & & & & & & & & & \\
\hline Nicosulfuron & & 6 & 988 & 2 & 1,634 & 4 & 1,716 & 9 & 998 & 1,690 & 12 \\
\hline Mesotrione & & 13 & 703 & 1 & 1,010 & 3 & 1,129 & 0 & 1,128 & 996 & 0 \\
\hline Sensitive $^{\mathrm{u}}$ & 2 & & & & & & & & & & \\
\hline Nicosulfuron & & 84 & 10 & 0 & 129 & 8 & 156 & 19 & 42 & 153 & 0 \\
\hline Mesotrione & & 0 & 94 & 0 & 146 & 0 & 180 & 0 & 53 & 160 & 3 \\
\hline Sensitive $^{t}$ & 1 & & & & & & & & & & \\
\hline Nicosulfuron & & 7 & 2 & 27 & 29 & 12 & 58 & 30 & 29 & 51 & 0 \\
\hline Mesotrione & & 11 & 6 & 34 & 25 & 4 & 37 & 0 & 73 & 44 & 0 \\
\hline
\end{tabular}

${ }^{\mathrm{z}}$ Sweet corn inbreds include three sensitive public inbreds (Ia5125, Ia5125sh2, and IL14h) and 37 proprietary inbreds from nine commercial breeding programs, including Abbott \& Cobb (Feasterville, PA) (3); Crookham (Caldwell, ID) (8); Del Monte USA (Rochelle, IL) (2); Green Giant (LeSueur, MN) (2); Harris Moran (Modesto, CA) (8); Illinois Foundation Seeds (Champaign, IL) (4); Mesa Maize (Olathe, CO) (1); Rogers Seeds/Syngenta (Boise, ID) (7); and Snowy River (Orbost, Australia) (2).

${ }^{\mathrm{y}} \mathrm{Cr} 1$ is a nicosulfuron- and mesotrione-sensitive sweet corn inbred from Crookham.

${ }^{\mathrm{x}} \mathrm{Cr} 2$ is a nicosulfuron- and mesotrione-tolerant sweet corn inbred from Crookham.

wHerbicide-sensitive field corn inbreds: B90, B94, or GA209.

$\mathrm{v}_{\mathrm{n}}=$ number of inbreds.

"Two sensitive inbreds with different responses to mesotrione (i.e., sensitive) and nicosulfuron (i.e., not killed) as inbreds per se.

${ }^{t}$ One sensitive inbred that appeared to segregate for tolerant and sensitive responses to nicosulfuron and mesotrione.

two inbreds were rated as tolerant because they were not dead or nearly dead; however, from 3 to 10 weeks after treatment, these plants were stunted. Although these two inbreds were not killed by nicosulfuron as were other sensitive inbreds, they appear to be homozygous for an allele that conditions sensitivity to nicosulfuron and mesotrione based on sensitive responses of $F_{1}$ and $F_{2}$ progeny from crosses with $\mathrm{Cr} 1$. These inbreds may possess another independent gene or several modifying loci with small effects that prevent nicosulfuron from killing them even though severe stunting occurs.

One inbred classified as sensitive appeared to be segregating for alleles conditioning herbicide responses. Eight of 26 inbred plants were sensitive to nicosulfuron or mesotrione. Among $115 \mathrm{~F}_{1}$ progeny of this inbred crossed with $\mathrm{Cr} 1,47 \%$ were sensitive, and 30 of $59 \mathrm{~F}_{1}$ progeny of this inbred crossed with field corn inbreds were sensitive to nicosulfuron.

Field CORN AND SWEET CORN INBRED CONTROLS. Among the control inbreds B90, B94, and Ia5125, 457 of 458 inbred plants, all $515 \mathrm{~F}_{1}$ plants from crosses with $\mathrm{Cr} 1$, and 339 of $343 \mathrm{~F}_{1}$ plants from crosses with GA209 were sensitive (Table 5). Only 2 of $292 \mathrm{~F}_{1}$ plants from crosses with $\mathrm{Cr} 2$ were sensitive.

\section{Discussion}

Forty-five sweet corn hybrid cultivars and 29 sweet corn inbreds evaluated in this study and representing germplasm from 12 independent commercial breeding programs were sensitive to nicosulfuron and mesotrione as the result of a single recessive gene that occurs at the same chromosomal location as a gene conferring sensitivity in the sweet corn inbred $\mathrm{Cr} 1$. None of the cultivars or inbreds appeared to be sensitive to these herbicides as a result of another independent gene. A single gene or closely linked genes in the sweet corn inbred $\mathrm{Cr} 1$ condition sensitivity to nicosulfuron, mesotrione, and at least seven other P450-metabolized herbicides and map to the same location on chromosome $5 \mathrm{~S}$ as the $n s f 1 /$ ben 1 gene, which is an insertion mutation of a CYP gene (Nordby et al., 2008; Pataky et al., 2006; Williams and Pataky, 2008; Williams et al., 2006). Nicosulfuron- and mesotrione-sensitive field corn inbreds GA209 and B90 have the same 392-bp insertion in the Nsfl/ Benl gene, whereas nicosulfuron- and mesotrione-sensitive inbreds Ia5125 and B94 do not have this insertion (Williams et al., 2006). Based on segregation of testcross progeny in this study, it appears that the gene(s) conditioning sensitivity in $\mathrm{Cr} 1$ and the other sweet corn inbreds and cultivars evaluated in this study may be the same insertion mutation as in GA209 and B90, a different mutation as occurs with Ia51525 and B94, or a different gene that is very closely linked to the Nsfl/Benl locus.

In addition to the hybrid cultivars evaluated in this study, 49 hybrid cultivars were classified in a previous study as heterozygous or homozygous sensitive for responses to foramsulfuron, mesotrione, and nicosulfuron (Pataky et al., 2008). Of those cultivars, 16 were tested in the present study and were allelic with $\mathrm{Cr} 1$. Because every nicosulfuron- and mesotrionesensitive sweet corn cultivar and inbred we have tested for allelism with $\mathrm{Cr} 1$ appears to have the same or closely linked genes conditioning sensitivity, it seems likely that many, if not all, of the other 33 cultivars from the previous study are allelic with $\mathrm{Cr} 1$. Thus, based on these two studies, it appears that at least $15 \%$ of nearly 500 sweet corn cultivars presently sold commercially in North America have a common genetic basis for sensitivity to P450-metabolized herbicides. These cultivars and inbreds include sugary, sugary enhancer, and shrunken-2 endosperm types from every major commercial breeding program. Cultivars in this group are grown commercially for processing and fresh consumption in nearly every market segment in North America and in many regions throughout the world. 
Table 5. Number of plants tolerant and sensitive to nicosulfuron and mesotrione for corn inbreds B90, B94, and Ia5125 and $\mathrm{F}_{1}$ hybrids from crosses of those inbreds with Cr1, GA209, and Cr2.

\begin{tabular}{|c|c|c|c|c|c|c|c|c|}
\hline \multirow[b]{3}{*}{ Inbred and herbicide } & \multicolumn{8}{|c|}{ Plants with tolerant or sensitive responses in each generation (no.) } \\
\hline & \multicolumn{2}{|c|}{ Inbred } & \multicolumn{2}{|c|}{ Inbred $\times \mathrm{Cr}^{\mathrm{z}}$} & \multicolumn{2}{|c|}{ Inbred $\times$ GA209 } & \multicolumn{2}{|c|}{ Inbred $\times \mathrm{Cr} 2^{\mathrm{x}}$} \\
\hline & Tolerant & Sensitive & Tolerant & Sensitive & Tolerant & Sensitive & Tolerant & Sensitive \\
\hline \multicolumn{9}{|l|}{$\mathrm{B} 90^{\mathrm{w}}$} \\
\hline Mesotrione & 1 & 88 & 0 & 103 & 0 & 98 & 45 & 0 \\
\hline \multicolumn{9}{|l|}{ B94 } \\
\hline Nicosulfuron & 0 & 54 & 0 & 62 & 0 & 58 & 13 & 0 \\
\hline \multicolumn{9}{|l|}{ Ia5 $125^{\mathrm{u}}$} \\
\hline Nicosulfuron & 0 & 62 & 0 & 83 & 0 & 18 & 87 & 0 \\
\hline Mesotrione & 0 & 73 & 0 & 94 & 0 & 22 & 92 & 2 \\
\hline
\end{tabular}

${ }^{\mathrm{z}} \mathrm{Cr} 1$ is a nicosulfuron- and mesotrione-sensitive sweet corn inbred from Crookham (Caldwell, ID).

${ }^{y}$ GA209 is a nicosulfuron- and mesotrione-sensitive field corn inbred from which the ben1 gene (i.e., nsfl gene) was originally identified and which has a 392-bp insertion in the Nsf1 gene sequence.

${ }^{\mathrm{x}} \mathrm{Cr} 2$ is a nicosulfuron- and mesotrione-tolerant sweet corn inbred from Crookham.

wB90 is a nicosulfuron- and mesotrione-sensitive field corn inbred that has the same 392-bp insertion in the Nsf1 gene sequence as GA209.

'B94 is a nicosulfuron- and mesotrione-sensitive field corn inbred that does not have the same 392-bp insertion in the Nsf1 gene sequence as GA209

"Ia5125 is a nicosulfuron- and mesotrione-sensitive sweet corn inbred that does not have the same 392-bp insertion in the Nsf1 gene sequence as GA209.

Despite the presence of a recessive allele(s) for herbicide sensitivity in prominent sweet corn germplasm, substantial injury may be relatively uncommon because many sweet corn cultivars are heterozygous for alleles conditioning herbicide response. Heterozygous cultivars are uninjured or suffer only minor injury under normal production practices. In this study and several previous studies investigating the inheritance of herbicide sensitivity (Bradshaw et al., 1994; Fleming et al., 1988; Green, 1998; Green and Ulrich, 1993; Kang, 1993; Pataky et al., 2006; Widstrom and Dowler, 1995), phenotypes were classified as tolerant or sensitive, and alleles conditioning tolerance were reported to be dominant to those conditioning sensitivity. In fact, alleles conditioning tolerance may be partially dominant, and under certain circumstances, plants heterozygous for alleles conditioning tolerance and sensitivity may have an intermediate response to these herbicides. In this study in 2006, intermediate responses occurred on heterozygous cultivars and on plants in segregating generations presumed to be heterozygous when a $1.5 \times$ rate of mesotrione was applied. In another study (Pataky et al., 2008), 47 sweet corn cultivars that were heterozygous for alleles conditioning herbicide response displayed intermediate responses to nicosulfuron, mesotrione, and foramsulfuron, and levels of injury appeared to be affected by environmental conditions as well as the genotype of the cultivar at the locus controlling herbicide response. Injury to heterozygous cultivars in the previous study was about 1.5 to 2.3 times greater than injury to homozygous tolerant cultivars, but was considerably less than injury to homozygous sensitive cultivars that often were severely injured or killed.

The results of Landi et al. (1989) and Volenberg et al. (2006) provide further evidence of intermediate responses of heterozygous hybrid cultivars. Landi et al. (1989) observed an intermediate response to chlorsulfuron, a different P450metabolized sulfonylurea herbicide, in crosses of tolerant (T), Va85 and Mes44, by sensitive (S), B73 and B79, field corn inbreds compared with crosses of the two tolerant inbreds and crosses of the two sensitive inbreds. Root length and shoot growth were affected by the genotype of the hybrid and dosage of chlorsulfuron applied. At low dosages (e.g., $0.25 \mathrm{ng} \cdot \mathrm{g}^{-1}$ ), root length of $\mathrm{T} \times \mathrm{S}$ and $\mathrm{T} \times \mathrm{T}$ hybrids was similar. At high dosages (e.g., $1 \mathrm{ng} \cdot \mathrm{g}^{-1}$ ), root length of $\mathrm{T} \times \mathrm{S}$ and $\mathrm{S} \times \mathrm{S}$ hybrids was similar. At intermediate dosages (e.g., $0.625 \mathrm{ng} \cdot \mathrm{g}^{-1}$ ), root length of $\mathrm{T} \times \mathrm{S}$ hybrids was intermediate to that of $\mathrm{T} \times \mathrm{T}$ and $\mathrm{S} \times \mathrm{S}$ hybrids. Although the chlorsulfuron-sensitive inbreds examined by Landi et al. (1989) were unaffected by nicosulfuron or mesotrione and did not appear to be allelic for the mutant CYP genes in GA209 or Cr1 (J.K. Pataky, unpublished data), we propose that a similar dose-response relationship may occur for hybrids that are homozygous tolerant, heterozygous, and homozygous sensitive to nicosulfuron and mesotrione due to the CYP gene(s) on chromosome 5S. In accordance with this hypothesis, results of a preliminary greenhouse study (Volenberg et al., 2006) demonstrate that following applications of mesotrione in dose-response studies similar to those of Landi et al. (1989), biomass of a sweet corn hybrid heterozygous for CYP alleles from $\mathrm{Cr} 1$ and $\mathrm{Cr} 2$ was intermediate to that of nearisogenic, homozygous tolerant, and homozygous sensitive hybrids.

Although the plant materials in this study were evaluated only for responses to mesotrione and nicosulfuron, the CYP gene(s) on chromosome 5S appear to affect metabolism of several other herbicides (Barrett et al., 1997; Green, 1998; Green and Ulrich, 1993; Nordby et al., 2008; Pataky et al., 2006; Williams et al., 2005; Williams and Pataky, 2008). Thus, sensitive inbreds and homozygous sensitive or heterozygous hybrid cultivars in this study may be affected by other P450metabolized herbicides. Therefore, it seems pragmatic to determine more completely the range of herbicides metabolized by the CYP genes on chromosome 5S. Similarly, it may be useful to identify if other genes affect metabolism of nicosulfuron and mesotrione, such as genes in the two sweet corn inbreds that were stunted but not killed by nicosulfuron. In the past, we have observed different degrees of sensitive responses 
to mesotrione (i.e., different levels of visual estimates of "bleaching" symptoms) among inbred lines selfed from the cross of $\mathrm{Cr} 1 \times \mathrm{Cr} 2$, which indicates that other genes have modifying effects on responses conditioned by the CYP gene(s) on chromosome 5S (J.K. Pataky, unpublished data).

A number of different CYP genes occur in corn, of which only some are associated with herbicide metabolism (Frey et al., 1995, 1997; Persans et al., 2001). In addition to the cluster of four CYP genes identified by Williams et al. (2006) on chromosome 5S, another cluster of four CYP genes on chromosome $4 \mathrm{~S}$ is related to production of DIMBOA (Frey et al., 1995, 1997). These genes, designated $B \times 2$ to $B \times 5$, are closely related to the CYP71 family of CYP genes and encode four cytochrome P450 monooxygenases that are substrate specific. Persans et al. (2001) observed that CYP71C transcripts, encoding the third P450 in the DIMBOA biosynthetic pathway, were not induced in 2.5-d-old seedlings by the ALSinhibiting, sulfonylurea herbicide triasulfuron in combination with the herbicide safener naphthalic anhydride, but CYP71C3v2 transcripts, encoding the fourth P450 in DIMBOA synthesis, were additively induced in young seedlings by the combination of triasulfuron and naphthalic anhydride. Naphthalic anhydride and triasulfuron also induced expression of CYP genes on chromosomes 2 and 3. Thus, CYP genes affecting triasulfuron metabolism may be different from those affecting nicosulfuron and mesotrione metabolism. Also, the gene(s) affecting metabolism of chlorsulfuron appear to be different from the ones on chromosome $5 \mathrm{~S}$ based on our observations of mesotrione and nicosulfuron tolerance among chlorsulfuron-sensitive field corn inbreds and their crosses with Cr1 and GA209 (J.K. Pataky, unpublished data). Additional research that associates groups of $\mathrm{P} 450$-metabolized herbicides with the CYP genes or other genes and detoxification enzymes governing their rates of metabolism will allow for more informed decisions concerning risks of crop injury from herbicides.

Injury or the potential for injury to sweet corn from postemergence applications of herbicides has been a concern of the sweet corn industry for nearly two decades. Using a group of sweet corn hybrid cultivars and inbreds that were subject to injury in previous trials, we observed a common genetic basis for cross-sensitivity to P450-metabolized herbicides that was present in germplasm used throughout the sweet corn industry. Confirmation of the presence of a gene(s) conditioning sensitivity to nicosulfuron and mesotrione, and probably to several other P450-metabolized herbicides, provides an explanation for varied levels of herbicide injury and inconsistent responses of sweet corn cultivars under differing environmental conditions. Hybrid cultivars heterozygous for CYP alleles in which rates of herbicide metabolism may be intermediate to that of homozygous tolerant and homozygous sensitive cultivars are more likely to display the greatest genotype $\times$ environment interactions with regard to herbicide responses. This information provides a rational basis from which herbicide sensitivity in sweet corn can be addressed. Alleles that render germplasm sensitive should be eliminated from breeding populations, inbreds, and commercial cultivars. Genotypes of cultivars at loci affecting herbicide metabolism also should be considered when establishing usage rates for new and existing herbicides. Alternatively, injury to heterozygous cultivars may be reduced if herbicides are formulated with safeners that enhance the detoxification activity of cytochrome P450 enzymes. Finally, applicators should inquire about the genetic predisposition to injury of specific cultivars before using a P450-metabolized herbicide.

\section{Literature Cited}

Barrett, M. 1995. Metabolism of herbicides by cytochrome P450 in corn. Drug Metabol. Drug Interact. 12:299-315.

Barrett, M. 2000. The role of cytochrome P450 enzymes in herbicide metabolism, p. 25-37. In: A.H. Cobb and R.C. Kirkwoods (eds.). Herbicides and their mechanisms of action. CRC Press, Boca Raton, FL. Barrett, M., L.D. Bradshaw, N.D. Polge, R.J. Baerg, and C.G. Poneleit. 1994. Evidence for multiple herbicide metabolizing cytochrome P450 from maize. Weed Sci. Soc. Amer. Abstr. 34:60.

Barrett, M., N. Polge, R. Baerg, R. Bradshaw, and C. Poneleit. 1997. Role of cytochrome P450 in herbicide metabolism and selectivity and multiple herbicide metabolizing cytochrome P450 activities in maize, p. 35-50. In: K. Hatzios (ed.). Regulation of enzymatic systems detoxifying xenobiotics in plants. Kluwer Academic Publishers, Dordrecht, The Netherlands.

Bradshaw, L.D., M. Barrett, and C.G. Poneleit. 1994. Inheritance of bentazon susceptibility in a corn (Zea mays) line. Weed Sci. 42:641647.

Burton, J.D., E.P. Maness, D.W. Monks, and R.R. Robinson. 1994. Sulfonylurea selectivity and safener activity in 'Landmark' and 'Merit' sweet corn. Pestic. Biochem. Physiol. 48:163-172.

Diebold, S., D. Robinson, J. Zandstra, J. O'Sullivan, and P.H. Sikkema. 2003. Sweet corn (Zea mays) cultivar sensitivity to $\mathrm{AE}$ F130360. Weed Technol. 17:127-132.

Diebold, S., D. Robinson, J. Zandstra, J. O'Sullivan, and P.H. Sikkema. 2004. Sweet corn sensitivity to bentazon. Weed Technol. 18:982-987.

Fleming, A.A., P.A. Banks, and J.G. Legg. 1988. Differential responses of maize inbreds to bentazon and other herbicides. Can. J. Plant Sci. 68:501-507.

Frey, M., P. Chomet, E. Glawischnig, C. Stettner, S. Grun, A. Winklmair, W. Eisenreich, A. Bacher, R. Meeley, S.P. Briggs, K. Simcox, and A. Gierl. 1997. Analysis of a chemical plant defense mechanism in grasses. Science 277:696-699.

Frey, M., R. Kliem, H. Saedler, and A. Gierl. 1995. Expression of a cytochrome P450 gene family in maize. Mol. Gen. Genet. 246:100109.

Green, J.M. 1998. Differential tolerance of corn (Zea mays) inbreds to four sulfonlyurea herbicides and bentazon. Weed Technol. 12: 474-477.

Green, J.M. and J.F. Ulrich. 1993. Response of corn (Zea mays L.) inbreds and hybrids to sulfonylurea herbicides. Weed Sci. 41:508-516. Grey, T.L., D.C. Bridges, P. Raymer, D. Day, and D.S. NeSmith. 2000. Differential tolerance of fresh market sweet corn cultivars to the herbicides nicosulfuron and primisulfuron. HortScience 35:10701073.

Harms, C.T., A.L. Montoya, L.S. Privalle, and R.W. Briggs. 1990. Genetic and biochemical characterization of corn inbred lines tolerant to the sulfonylurea herbicide primisulfuron. Theor. Appl. Genet. 80:353-358.

Kang, M.S. 1993. Inheritance of susceptibility to nicosulfuron herbicide in maize. J. Hered. 84:216-217.

Landi, P., A. Vicari, and P. Catizone. 1989. Response of maize (Zea mays L.) inbred lines and hybrids to chlorsulfuron. Weed Res. 29:265-271.

Monks, D.W., C.A. Mullins, and K.E. Johnson. 1992. Response of sweet corn (Zea mays) to nicosulfuron and primisulfuron. Weed Technol. 6:280-283.

Morton, C.A. and R.G. Harvey. 1992. Sweet corn (Zea mays) hybrid tolerance to nicosulfuron. Weed Technol. 6:91-96.

Nordby, J.N., M.M. Williams, J.K. Pataky, D.E. Riechers, and J.D. Lutz. 2008. A common genetic basis in sweet corn inbred $\mathrm{Cr} 1$ for cross sensitivity to multiple cytochrome P450-metabolized herbicides. Weed Sci. 56:376-382. 
O'Sullivan, J. and P.H. Sikkema. 2002. Sweet corn (Zea mays) cultivar tolerance to primisulfuron. Can. J. Plant Sci. 82:261-264.

O'Sullivan, J. and W.J. Bouw. 1998. Sensitivity of processing sweet corn (Zea mays) cultivars to nicosulfuron/rimsulfuron. Can. J. Plant Sci. 78:151-154.

O'Sullivan, J., J. Zandstra, and P. Sikkema. 2002. Sweet corn (Zea mays) cultivar sensitivity to mesotrione. Weed Technol. 16:421-425.

O'Sullivan, J., P.H. Sikkema, and R.J. Thomas. 2000. Sweet corn (Zea mays) cultivar tolerance to nicosulfuron. Can. J. Plant Sci. 80:419423.

O’Sullivan, J., R.A. Brammall, and W.J. Bouw. 1995. Response of sweet corn (Zea mays) cultivars to nicosulfuron plus rimsulfuron. Weed Technol. 9:58-62.

Pan, G., X. Zhang, K. Liu, J. Zhang, W. Wu, J. Zhu, and J. Tu. 2006. Map-based cloning of a novel rice cytochrome P450 gene CYP81A6 that confers resistance to two different classes of herbicides. Plant Mol. Biol. 61:933-943.

Pataky, J.K., J.N. Nordby, M.M. Williams, II, and D.E. Riechers. 2006. Inheritance of cross-sensitivity in sweet corn to herbicides applied post emergence. J. Amer. Soc. Hort. Sci. 131:744-751.

Pataky, J.K., M.E. Meyer, J.D. Bollman, C.M. Boerboom, and M.M. Williams, II. 2008. Genetic basis for varied levels of injury to sweet corn hybrids from three cytochrome P450-metabolized herbicides. J. Amer. Soc. Hort. Sci. 133:438-447.

Persans, M.W., J. Wang, and M.A. Schuler. 2001. Characterization of maize cytochrome P450 monooxygenases induced in response to safeners and bacterial pathogens. Plant Physiol. 125:1126-1138.
Robinson, D.K., D.W. Monks, and J.R. Schultheis. 1994. Effect of nicosulfuron applied postemergence and post-directed on sweet corn (Zea mays) tolerance. Weed Technol. 8:630-634.

Robinson, D.K., D.W. Monks, J.R. Schultheis, and A.D. Worsham. 1993. Sweet corn (Zea mays) cultivar tolerance to application timing of nicosulfuron. Weed Technol. 7:840-843.

Sikkema, S.R., N. Soltani, P.H. Sikkema, and D.R. Robinson. 2008. Response of sweet maize (Zea mays L.) hybrids to halosulfuron. Crop Prot. 27:695-699.

Stall, W.M. and T.A. Bewick. 1992. Sweet corn cultivars respond differently to the herbicide nicosulfuron. HortScience 27:131-133.

Volenberg, D.S., M.M. Williams, II, J.K. Pataky, and D.E. Riechers. 2006. Responses of tolerant and sensitive sweet corn inbreds and near isogenic hybrids to postemergence herbicides with different modes of action. North Central Weed Sci. Soc. Abstr. 61:213.

Widstrom, N.W. and C.C. Dowler. 1995. Sensitivity of selected field corn inbreds (Zea mays) to nicosulfuron. Weed Technol. 9:779782

Williams, M.M., II and J.K. Pataky. 2008. Genetic basis of sensitivity in sweet corn to tembotrione. Weed Sci. 56:364-370.

Williams, M.M., II, J.K. Pataky, J.N. Nordby, D.E. Riechers, C.L. Sprague, and J.B. Masiunas. 2005. Cross-sensitivity in sweet corn to nicosulfuron and mesotrione applied postemergence. HortScience 40:1801-1805.

Williams, M., S. Sowinski, T. Dam, and B.L. Li. 2006. Map-based cloning of the nsflgene of maize. Program and Abstracts of the 48th Maize Genetics Conference, Pacific Grove, CA. (Abstr). 